\title{
Role of Waste Collection Efficiency in Providing a Cleaner Rural Environment
}

\author{
Florin-Constantin Mihai ${ }^{1, *}$ and Adrian Grozavu ${ }^{2}$ (D) \\ 1 Department of Research, Faculty of Geography and Geology, Alexandru Ioan Cuza University, Carol I Blvd, \\ Nr. 20A, RO-700505 Iasi, Romania \\ 2 Department of Geography, Faculty of Geography and Geology, Alexandru Ioan Cuza University, \\ Carol I Blvd, Nr. 20 A RO-700505 Iasi, Romania; adriangrozavu@yahoo.com \\ * Correspondence: mihai.florinconstantin@gmail.com
}

Received: 30 October 2019; Accepted: 26 November 2019; Published: 2 December 2019

check for updates

\begin{abstract}
The exposure of rural communities to illegal waste dumping practices associated with the lack of or poor waste collection schemes prior to the closure of rural dumpsites under EU regulations and the role of collection efficiency afterward in reducing this critical environmental threat constitutes a key issue in rural Romania. The present study reveals huge amounts of household uncollected waste released into the natural environment outside the official statistics of rural dumpsites. Despite the expansion of waste collection coverage towards rural areas since 2010, the problem of illegal dumping practice is difficult to solve. The improvement of collection efficiency, better law enforcement, and surveillance of environmental authorities coupled with educational and environmental awareness are necessary steps to combat this bad practice. A circular economy paradigm must be enacted in rural regions through separate collection schemes and to improve cost-efficient alternatives, such as home composting, and traditional and creative reuse practices, particularly in less developed regions.
\end{abstract}

Keywords: rural area; waste management; pollution; environment; recycling; circular economy

\section{Introduction}

Uncollected wastes across rural communities are susceptible to uncontrolled disposal via open dumping or open burning practices, with direct impacts on environmental factors (air-water-soil nexus) and public health. Rural areas are often neglected by formal waste management services due to a complex of factors, such as geographical barriers, sparse settlements, low population densities, poorer socioeconomic conditions, long distances from urban areas, transportation costs, etc. The characteristics of household waste are variable across different households, villages, regions, and countries [1,2].

Collection rates of wastes generated may significantly vary from one country to another as less than $50 \%$ in the case of low-income countries, $50 \%$ to $80 \%$ in the case of middle-income countries, and over $90 \%$ in the case of high-income countries but are rarely $100 \%$ [3].

Illegal waste dumping of solid waste raises many problems even in developed countries [4,5], transition economies [6,7], or developing countries, where rural areas are frequently exposed to such environmental threats [8]. The increasing amounts of waste generated across the globe raise more difficulties in dealing with proper waste management activities at the regional and local scale involving urban or rural municipalities [9,10]. The old non-compliant landfills are replaced by new regional integrated waste management facilities, which must include rural communities [11,12].

Solid waste collection schemes cover only part of the rural population and the burning of waste and animal feed with food scraps seems to be prevalent options in rural communities, as is the case in Brazil, for example [13]. The spatial and temporal distribution of rural waste characteristics can be extremely non-homogenous in emerging economies [14]. Organic waste could provide a source of 
biomethane for cities [15], but for rural areas, such initiatives are scarcely seen in Eastern Europe [16], where animal feed and home composting are traditional routes for organic fraction beside landfills or illegal dumping practices [17]. New EU members struggle to mitigate waste dumping practices across rural settlements and to provide reliable waste management services [18]. These countries are the worst performers in terms of municipal waste management practices [19]. However, older EU member states (e.g., Spain) are still facing the problem of illegal dumping practices in rural areas and regional authorities must take proper actions to deal with it [20]. Open dumping practices were a widespread option across rural Romania because of the poor facilities and lack of investments in this sector. Some improvements have been seen since EU adhesion in 2007, but rural waste dumping practices remain a serious environmental threat. Romania has significant gaps between urban and rural areas in terms of socio-economic development, where distant rural communities from urban areas are exposed to serious poverty and social exclusion issues. The North-East Region has one of the lowest per capita gross domestic product (GDP) at current market prices by EU regions (NUTS2) during 2007-2016 despite an increasing trend in the later years [21]. Under such circumstances, waste management activities should pay special attention to rural communities, particularly in the case of a peripheral region at the EU eastern border that is prone to illegal dumping practices.

The aim of the present study was to reveal the exposure of rural communities in the North-East Region of Romania to illegal waste dumping practices associated with the lack of or poor waste collection schemes prior the closure of rural dumpsites under EU regulations and to point out the role of collection efficiency afterward in reducing this critical environmental threat in rural Romania, supported by activities that promote a rural circular economy framework. In this regard, several objectives were further taken into consideration: (i) To point out the major gaps between the amounts of uncollected household waste based on poor rural waste collection coverage (during 2003-2009) compared to those reported to be disposed of in the wild dumps (2010); (ii) a multi-scale approach at the county and rural municipality levels (commune) combined with relevant collection efficiency scenarios for middle-income countries supported by spatial analysis in order to reveal the magnitude of waste dumping practices in a peripheral EU region; (iii) to calculate the amounts of rural uncollected household waste at the county level during 2010-2016 as a further primary source for illegal waste dumping practices; (iv) spatial analysis of uncollected household waste (2012 vs. 2015) at the commune level in Neamt county, based on collection efficiency derived to the latest available data on collection rates provided by environmental authorities; and (v) to support the traditional activities of organic waste fraction (e.g., home composting, animal feed) and the transition towards a rural circular economic framework by promoting the 3, 6, or 9 Rs policy (reduce, reuse, repair, recovery, refurbish, repurpose, remanufacture, recycle, refuse) at household and community levels. This study argues that official statistics regarding uncontrolled waste disposal practices must be confronted with sound estimation methods of uncollected waste flow to better understand the potential pollution issues within the study area and to explain the geographical disparities.

\section{Materials and Methods}

\subsection{Study Area}

The North-East Region of Romania covers 36.850 sq.km (representing $15.46 \%$ of the territory of the country), is equivalent to a NUTS-2 region with 3.3 million inhabitants, and includes six counties (equivalent to the NUTS3 regions), such as Botosani, Iasi, Suceava, Neamt, Vaslui, and Bacau, and 46 urban areas (Figure 1). 


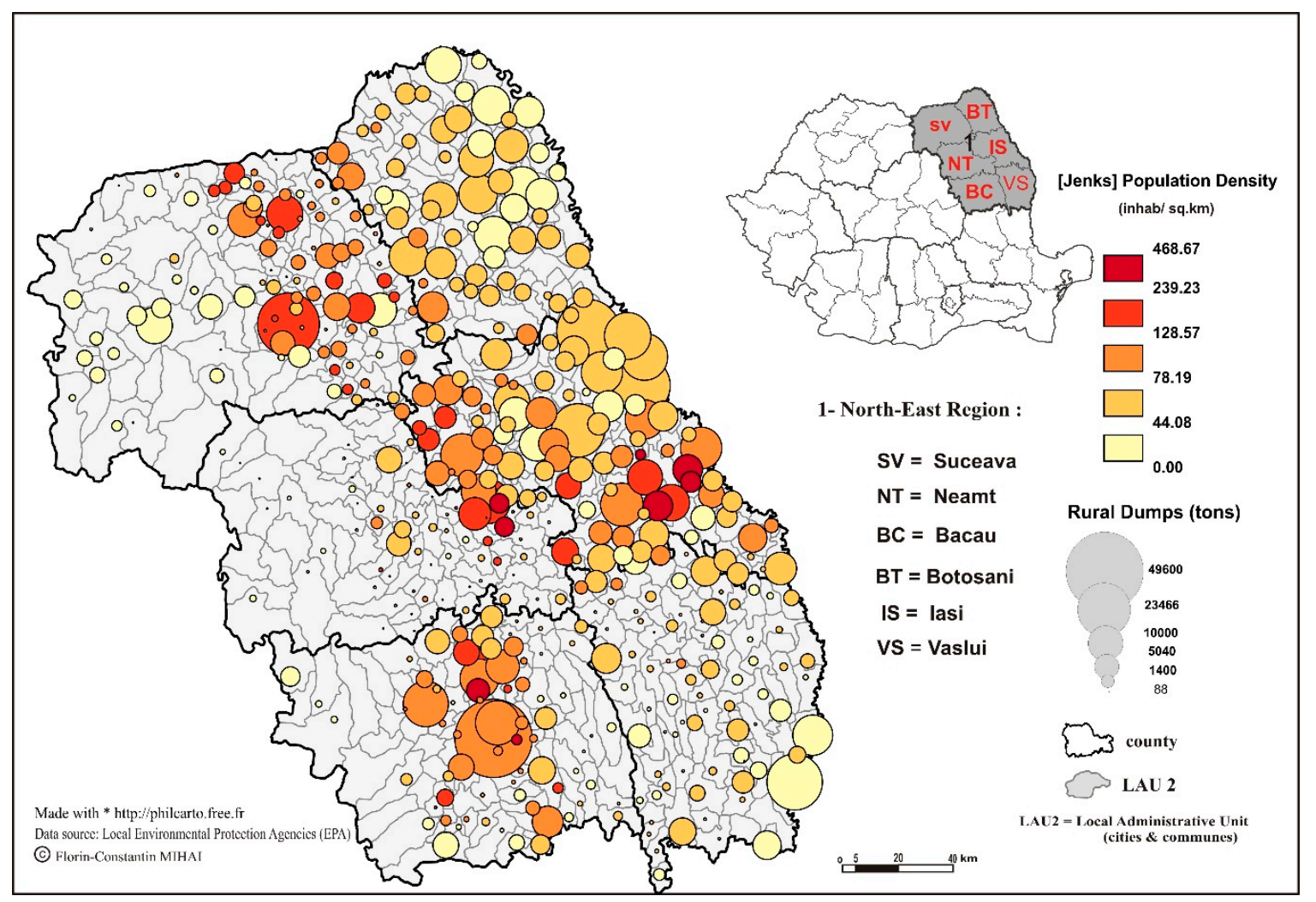

Figure 1. Spatial analysis of waste amounts disposed of in rural dumps.

NUTS 2 are the basic regions of the application of regional policies in EU, including those related to the environment and waste management sectors, but in Romania, such regions have no governmental responsibilities. On the other side, each county is ruled by a County Council, which supervises the implementation of such policies at the local administrative unit level (cities and communes equivalent to the LAU-2 level). The geographical conditions of the North-East Region are given by a mountainous (Eastern Carpathians) sector ( $28 \%$ of the territory) in the western part, a subcarpathian zone (12\%) in the central area, and a plateau zone $(60 \%)$, which entirely covers the eastern counties of the region, such as the Botosani, Iasi, and Vaslui counties [22]. Most of the population lives in rural areas (58\%) according to the Population Census from 2011, in 506 communes with 2361 villages. Therefore, a sound rural waste management sector should be a crucial environmental objective in the study area.

\subsection{The Closure and the Monitoring Process of Wild Dumps Parameters}

The lack and poor coverage of waste collection services (WCSs) across rural municipalities has contributed to the disposal of rural household waste in wild dumps. These sites are uncontrolled, without any environmental protection measures, threatening the local environment and public health. Local environmental protection agencies and National Environmental Guard via County Commissariats inventoried these sites between 2009-2010 with the aid of local municipalities. According to the Government Decision no. 345 regarding the landfill of waste, all rural dumpsites should be closed and rehabilitated until July 2009. Data concerning dumpsite volumes are counted at the rural municipality level (commune). The maps we obtained reveal some spatial patterns within the North-East Region, which are further examined in the results and discussion sections. Dumpsites volume data expressed in cubic meters are based on pile volume estimations by determining the area of the base and then multiplying it by the average height of the pile. In many cases, the base of a pile resembles a rectangle where the area is the length times width $(\mathrm{L} \times \mathrm{W})$. There is no information about weighing such sites; in fact, few urban landfills have weighing systems in Romania and most waste statistics are based on volume estimations provided by waste operators taking into account the garbage truck capacity. In the 
case of Iasi county, the average height of the dump is provided, and the volume is calculated using the rectangle geometry. The conversion of the volume data of wild dumps in kilograms is performed using a specific density of $400 \mathrm{~kg} / \mathrm{m}^{3}$.

Wild dumps are frequently smaller than 1 ha with a sparse distribution across the surroundings. The commingled wastes are not compacted or soil covered, and the density of waste is lower than conventional urban landfills $\left(700-900 \mathrm{~kg} / \mathrm{m}^{3}\right)$. Some communes had no reported dumps on their administrative territory despite the poor coverage of WCS in rural areas during 2003-2009. In other cases, poor data about their area (sq.m) is available. The monitoring process of these wild dumps scattered across rural areas was performed by local authorities under the supervision of environmental institutions. This is the most comprehensive empirical data about wild dumps at the commune level in Romania. Therefore, the year 2010 is the best option to analyze the underestimation level of rural waste dumping practices in the context of poor waste management facilities from previous years at the regional scale (NUTS2).

\subsection{Assessment of Household Waste Generated and Uncollected}

The paper estimated the amounts of household waste generated and uncollected at the county level based on the per-capita waste generation rate as follows:

$$
\mathrm{Q}_{\text {hwu }}\left(\mathrm{t} . \mathrm{yr}^{-1}\right)=\mathrm{P}_{\text {noWCS }} \times \mathrm{Grw} \times 365 / 1000,
$$

where $\mathrm{Q}_{\mathrm{hwu}}$ is the amount of household waste generated and uncollected by waste operators (t.yr. $\left.{ }^{-1}\right)$; $\mathrm{P}_{\text {noWCS }}$ is the number of inhabitants with no access to WCS; and Grw is the per-capita waste generation rate in rural areas $\left(\mathrm{kg}\right.$. inhab.day $\left.{ }^{-1}\right)$.

The paper used three rural per-capita waste generation rates, such as: $0.31 \mathrm{~kg}$.inab.day ${ }^{-1}$ as a specific regional rate [23], $0.4\left(\mathrm{~kg}\right.$. inhab.day $\left.^{-1}\right)$ as the national flat rate [24], and $0.5 \mathrm{~kg}$.inhab.day ${ }^{-1}$ as an above-national-average rate. These amounts of household waste generated are related as a ratio to the total amounts of household waste disposed in wild dumps. Local environmental protection agencies calculate the amounts of municipal waste generated and uncollected by waste operators in rural areas using a waste generation rate of $0.4 \mathrm{~kg}$.inhab.day ${ }^{-1}$ as suggested by environmental authorities [25], but the data is not available at the commune level. The waste collection coverage rates are not broken down per local administrative unit level (cities and communes); therefore, waste statistics are aggregated at the county level in environmental reports. This fact limits the possibility of evaluating the uncollected household waste flow across the communes of a wider geographical area, but collection efficiency scenarios could fill this gap. This formula was applied in the case of counties and communes where waste collection coverage is not $100 \%$.

The share of dumpsites (total amount of waste disposed of in dumps at the county level) as the ratio of total household waste generated and uncollected was determined for each county to reveal the magnitude of this practice. In this particular case, the timeline covers 7 years (2003-2009) where few rural inhabitants have access to formal WCSs, and waste dumping practices were a widespread option among rural communities until the closure of rural dumpsites in 2009-2010. The uncollected household waste was further calculated at the county level (2010-2016) and commune level (Neamt county as a case study, 2012 vs. 2015) derived from rural inhabitants without access to WCSs, and on the other hand, uncollected household waste related to the gaps of waste collection schemes based on the lower and upper ranges of collection efficiency scenarios specific to middle-income countries like Romania. The use of these three waste generation rates indicates different perspectives of waste dumping practice from each county to another.

The role of the similar fraction as household waste fraction generated by economic agents and the local institutions is further discussed. Collection efficiency scenarios were used to reveal, on the one hand, that the amounts of uncollected household waste are much larger than those disposed of in the 
wild dumps (2010), and on the other hand, to point out that rural communities are still exposed to illegal waste dumping practices.

\subsection{Worst- vs. Best-Case Scenario Analysis}

No waste collection services scenario (noWCS) was used to calculate the amounts of household waste generated and uncollected in each commune during a year (2010) based on the number of inhabitants provided by the Population Census 2011. In this scenario, the number of inhabitants with no access to WCS is equal to the population of each commune.

This scenario was correlated with the total waste disposed in the dumps at the commune scale to reveal the underestimation level of waste dumping practices, particularly in the western counties of the region. There is no available data at the rural municipal level (commune) concerning waste collection coverage for 2004-2009, only at the county level. This is the reason why the scenario analysis must be taken into consideration at the local administrative level (LAU2 = commune). The "best-case scenario" refers to the amounts of household waste generated by the rural population without access to WCS. For rural municipalities, where collection coverage is $100 \%$ (according to the environmental or local authorities), a full collection efficiency with no illegal dumping practices was assumed.

\subsection{Collection Efficiency Scenarios (Low and Upper Ranges)}

Field observations point out that even rural communities with a full waste collection coverage are facing waste dumping practices, suggesting that collection efficiency is not $100 \%$. This fact is confirmed by local authorities, such as Manastirea Casin commune (Bacau county), where collection efficiency was $30 \%$ in 2010 and by previous publications $[26,27]$.

Two scenarios were taken into consideration, such as WCS40 (collection efficiency is $40 \%$ as a low range) and WCS70 (collection efficiency is 70\% as an upper range), which are more realistic than the previous worst- and best-case scenarios. These scenarios combine the amounts of uncollected household waste fed by two main sources: (i) Rural inhabitants without access to WCSs (Equation (1)) and (ii) the amounts of uncollected household waste derived from low $(40 \%)$ or upper collection efficiency $(70 \%)$ ranges of those inhabitants connected with such services as follows:

$$
\text { Qhwut }=(\text { Qhwp }- \text { Qhwp } \times 0.4)+\text { Qhwu, }
$$

where Qhwut is the total amounts of uncollected household wasteby formal WCS, and Qhwp is the amounts of household waste generated by population with access to WCS using the per-capita generation rate given in Section 2.3.

$$
\text { Qhwut }=(\text { Qhwps }- \text { Qhwps } \times 0.7)+\text { Qhwu. }
$$

These are consistent with collection rates for middle-income countries (like Romania) ranging between $50 \%$ and $80 \%$ [3], with the mention that rural communities are expected to have a lower collection efficiency than urban areas due to following factors: sparse settlements and lower density, poorer socioeconomic conditions, geographical isolation, scattered waste collection points, low collection frequency, large distances from landfills, recycling, and waste treatment facilities, etc. Thus, lower ( $40 \%)$ and upper ranges $(70 \%)$ were taken into consideration to calculate the rural uncollected household waste flow at the county level derived from the gaps in the rural waste collection schemes.

\subsection{Collection Efficiency Based on the Rural Household Collection Rate}

The current rural waste dumping practices following the closure of rural wild dumps in 2009-2010 were examined in our study, with a particular focus on Neamt county. The most recent local environmental report stipulates that despite a significant increase of waste collection coverage among 
rural residents (5.24 times, from 53,089 in 2009 to 278,167 inhabitants in 2015), the collection rate of household waste by waste operators is much lower (1.5 times), suggesting serious gaps in the rural waste collection schemes across the county [28].

In this case, collection efficiency (Cef) was determined using the ratio of the collection rate calculated on a per-capita basis (kg.inhab.day ${ }^{-1}$ ) during 2010-2015 (latest data available) by a local environmental protection agency to national and regional waste generation rates as shown in Table 1 .

Table 1. Ratio of rural household collection rate to national and regional generation rates.

\begin{tabular}{cccc}
\hline Year & Rural Collection Rate & $\begin{array}{c}\text { Grw = 0.4 } \\
\text { Cef (\%) }\end{array}$ & $\begin{array}{c}\text { Grw = 0.31 } \\
\text { Cef (\%) }\end{array}$ \\
\hline 2010 & 0.252 & 63 & 40 \\
2011 & 0.200 & 50 & 64.51 \\
2012 & 0.205 & 51.25 & 66.12 \\
2013 & 0.130 & 32.5 & 42 \\
2014 & 0.152 & 38 & 49 \\
2015 & 0.146 & 36.5 & $47 \%$ \\
\hline
\end{tabular}

The average rural collection rate for the period 2010-2015 was $0.18 \mathrm{~kg}$.inhab.day ${ }^{-1}$ in Neamt county, which has a ratio of $45 \%$ of the national rural waste generation rate $\left(0.4 \mathrm{~kg}\right.$.inhab.day $\left.{ }^{-1}\right)$ and $58 \%$ in case of the regional generation rate $\left(0.31 \mathrm{~kg}\right.$.inhab.day $\left.{ }^{-1}\right)$. These values are consistent with previous low and upper ranges scenarios $(40-70 \%)$, but the regional waste generation rate was further taken into consideration, resulting in a collection efficiency of 60 (WCS60) in rural Neamt county. This is a different approach, but it can be applied in rural regions where data about rural collection rates are available and they must be below the national waste generation rates stipulated in environmental reports. Rural waste dumping practices were further analyzed in 2012 (where some communes are not covered by WCS) and 2015, where all communes are served by public or private waste operators. The amounts of uncollected household waste were calculated for both years using the equation from Section 2.3 and applying WCS60 as follows:

$$
\text { Qhwut }=(\text { Qhwps }- \text { Qhwps } \times 0.6)+\text { Qhwu. }
$$

The amounts of uncollected household waste from rural inhabitants without access to WCS were determined for 2012. In the case of 2015, amounts of uncollected household waste derived mainly from the gaps in waste collection systems (WCS60). Spatial analysis revealed rural regions most exposed to illegal dumping practices in 2012 and 2015.

\section{Results and Discussion}

\subsection{Geographies of Dumpsites}

The total amounts of waste disposed of in the wild dumps are 1.403 million tons at the regional level with larger amounts disposed in Iasi county $(552,102.8 \mathrm{t})$ and lowest in Neamt county $(35,318 \mathrm{t})$. Figure 1 points out the geography of dumps at the regional scale as follows:

- Eastern counties of the North-East Region (Botosani, Iasi, Vaslui) that overlap on the Moldavian Plateau have a homogenous higher density of population and large amounts of waste disposed of in wild dumps; and

- The western counties of the region (Suceava, Neamt, Bacau) have a low density of population and smaller dumpsites in the mountain sector (Eastern Carpathians-the western half of counties) and high density and larger amounts of dumps in the proximity of the corridor valleys of Suceava, Moldova, and Siret rivers. 
The subcarpathian depression sector, which is a favorable geographical area for the development of human settlements, has a high density and larger amounts disposed of in the dumps (Neamt and Bacau counties). However, peripheral areas and distant rural communities from urban centers are less populated. That is the case of rural communities from the eastern part of Bacau county, southeast of Neamt county, and western and central areas of Vaslui county. The variation of the total dump capacity $(t)$ is significant from each commune to another, ranging from smaller wild dumps $(<100 t)$ to larger than 30,000 t. A diverse geographical distribution is observed between and within counties as shown in Figure 2. The waste dumping amounts expressed as per capita provide an insightful geographical comparison between rural municipalities.

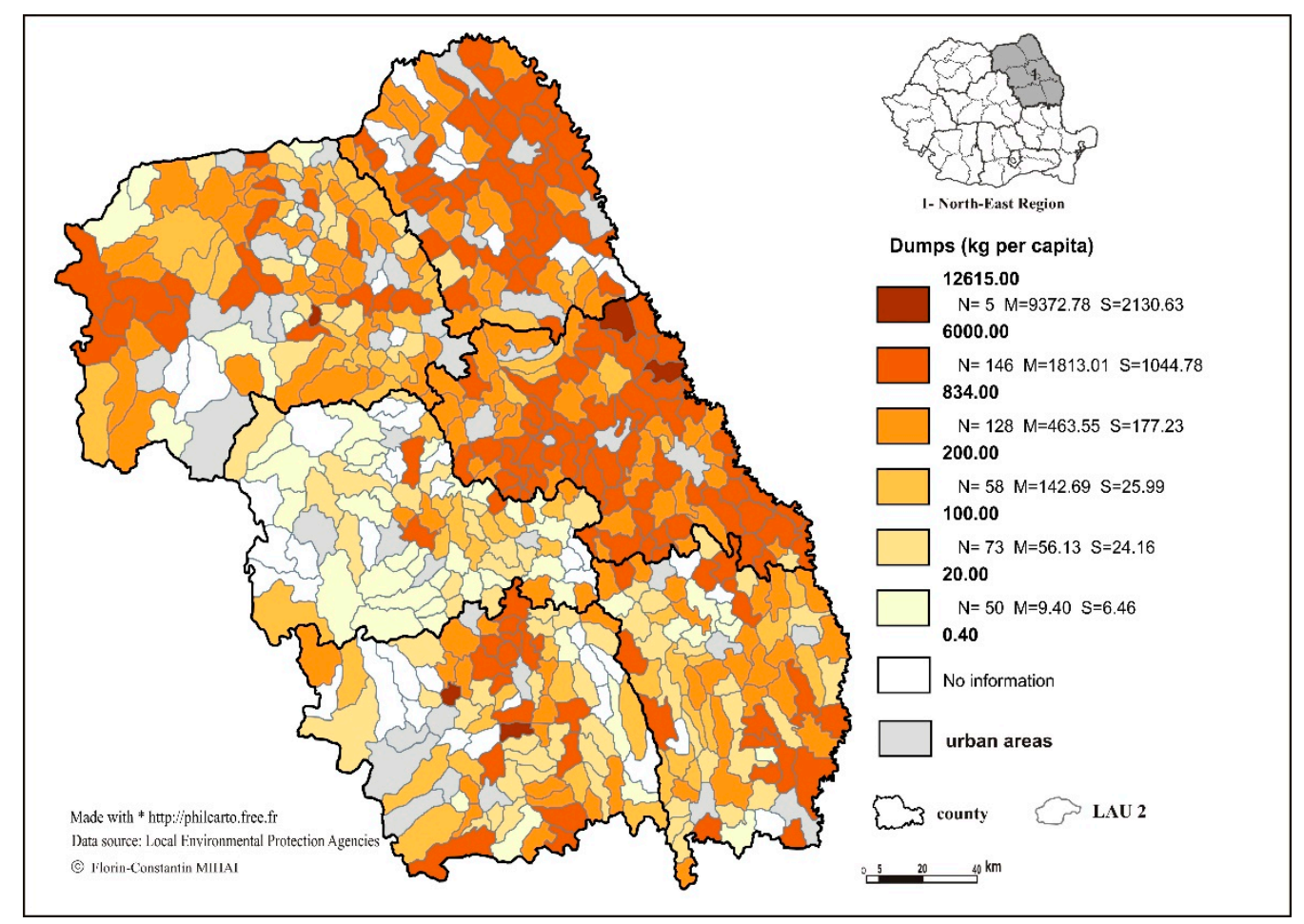

Figure 2. Per-capita analysis of waste amounts from dumps at the commune level in 2010.

A strong variation is observed in the western counties where the landscape varies, such as mountain areas, subcarpathian depressions and hills, valleys, and plateau areas with particular socio-economic features. The lower values of dumps ( $<100 \mathrm{~kg}$.inhab) are found in 123 rural municipalities, particularly in the mountain sector of western counties. The regional average of the study area is $834 \mathrm{~kg}$ per capita per total dump capacity reported at the commune level. There are 151 communes with values above this regional average, with a particular focus across Iasi and Botosani counties.

A rural inhabitant generates $113.15 \mathrm{~kg}$.inhab. $\mathrm{yr}^{-1}$ of household waste if the per-capita waste generation rate is $0.31 \mathrm{~kg}$.inhab.day ${ }^{-1}, 146 \mathrm{~kg}$.inhab. $\mathrm{yr}^{-1}$ according to national average rate, or $182.5 \mathrm{~kg}$.inhab. $\mathrm{yr}^{-1}$ if the generation rate is above the national flat rate $\left(0.5 \mathrm{~kg}\right.$.inhab.day $\left.{ }^{-1}\right)$. In all three cases, the amount of household waste generated is less than $200 \mathrm{~kg}$.inhab. $\mathrm{yr}^{-1}$.

The map in Figure 2 reveals that several rural communities reported lesser amounts of household waste disposed of in wild dumps than those generated by one inhabitant in a year, in the context of poor waste collection coverage at the regional level. In fact, there are 181 rural communities in this situation providing solid arguments towards a poor monitoring process of waste dumping practices, and on the other hand, a higher susceptibility of river dumping practices in mountain and subcarpathian areas combined with backyard burning practices $[27,29]$. Such waste disposal routes could explain the lower values than the regional average ( $<800 \mathrm{~kg}$.per capita) of the western counties, but there are 50 communes with values even below $20 \mathrm{~kg}$.per capita/dump/commune. In such cases, there is no 
doubt that open dumping practices are heavily underestimated across rural communities, with this issue being further analyzed in Section 3.3.

Floodplains and riverbeds are frequently exposed to the illegal dumping of solid waste because of improper waste management facilities in rural areas.

The amounts of waste disposed of in riverbeds are diverted from local wild dumps exposed to floods. Also, wild dumps located on floodplains are exposed to flash floods, which transport the wastes into downstream localities [30]. The same river dumping practices occur in rural Poland as shown by Malinowski et al., [31] along with the Wisłok and Lubatówka river courses. Illegal dumpsites were also detected mainly in rural areas close to agricultural land in the Canary Islands [32]. Municipal landfills create specific ecosystems where some plant species can be dangerous to surrounding agricultural lands [33], but rural dumpsites are much smaller with lower amounts of waste disposed of and the closed sites are often covered by ruderal species.

Eastern Europe is prone to illegal dumping practices because waste collection coverage is not $100 \%$, especially in rural areas, as confirmed in post-soviet countries, such as Ukraine, Belarus, Georgia, Moldova, and Russia [34]. The lack of a waste-sorting culture, poor infrastructure, and landfill prevalence are additional issues that such countries are facing [35].

Open burning is another waste disposal option of households' uncollected waste across rural communities. Combustible wastes accumulate in open piles (backyards, roadsides, or floodplains) containing mixed fractions, such as biowaste (food waste, garden waste, wood), plastics, textiles, paper and cardboard, and occasionally hazardous items (electronic waste, batteries, etc.) or sawdust. River dumping and open burning practices could divert a certain part of uncollected household waste, decreasing the amount of waste in dumpsites. This data seems to be questionable at the local scale due to the high number of communes that have reported lower volumes of dumpsites within their administrative area.

\subsection{Poor Waste Collection Services Contribute to Large Amounts of Uncollected Household Waste}

The lack of waste collection services in rural areas was the norm in the North-East Region of Romania prior to EU accession (2007) as Figure 3 shows. Such services were non-existent in Vaslui county during 2003-2010, $1 \%$ to $2 \%$ in Botosani county (2003-2007), less than $5 \%$ in Iasi county (2003-2008), and less than 10\% in Suceava county (2003-2006). Neamt county has a constant range (9-11\%) during 2003-2008, with an increase of $15 \%$ in 2009. Open dumping was a widespread practice across rural communities until July 2009. Local authorities were obliged to close such dumpsites and on the other hand, to establish their own waste management services or to delegate this amenity towards a private waste operator. Rural population coverage is more than $50 \%$ only in Suceava (71, $24 \%)$ compared to Vaslui $(0.07 \%)$ in 2009 . Rural communities have been exposed to unsound waste management practices, such as open dumping, river dumping, and open burning of household waste.

The expansion of WCSs towards rural areas has emerged since 2008 with a peak in 2009-2010. Botosani and Suceava have the highest collection coverage rates after the closure of dumpsites followed by Iasi county, and in the later years by Neamt and Bacau counties. Vaslui county represents the worst case situation during the full timeline analysis (2003-2016), facing serious illegal waste dumping and open burning practices across rural communities due to the lack of waste collection schemes.

Local dumpsites were the main option for household waste disposal across rural communities in the eastern counties compared to the western half of Bacau, Neamt, and Suceava. Eastern Carpathians favored the development of human settlements along the river valleys (Bistrita, Trotus, Moldova) and its tributaries. Such open dumps were often located in the proximity of riverbanks, but river dumping practices were more widespread disposal practices among mountain localities [30]. Such localities impose particular challenges for the waste management sector in terms of waste collection, transport, and location of waste treatment facilities [36]. 


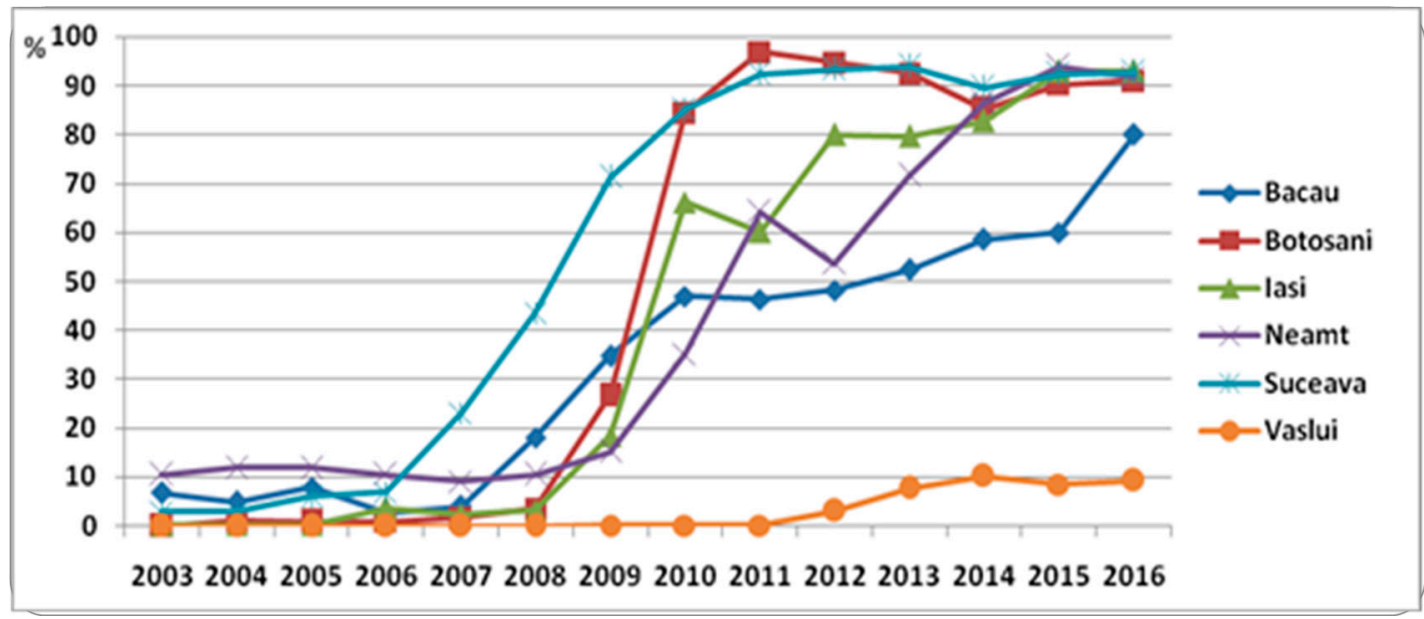

Figure 3. Rural population coverage with waste collection services (WCSs) 2003-2016.

Poor waste collection coverage contributed to large amounts of uncollected household waste during 2003-2009 across rural municipalities being susceptible to be uncontrolled disposal in the surroundings of wild dumps. The total amount calculated is $1.55 \mathrm{MT}\left(0.31 \mathrm{~kg}\right.$.per capita.day $\left.{ }^{-1}\right)$ or 2 MT (0.4 kg.per capita.day $\left.{ }^{-1}\right)$ across the North-East region. At first glance, the regional value of uncollected household waste (1.55 MT) is closer to those disposed of in the dumps (1.4 MT) suggesting that dumps represent $90.5 \%$ of disposal practice of household waste in rural areas.

However, at the county level, there are significant differences concerning the ratio of dumps in total uncollected household waste, ranging from $14 \%$ in Neamt county to $164 \%$ in Iasi county as shown in Table 2. Firstly, dumps cover a poor share of uncollected household waste, suggesting an improper monitoring process of rural dumps performed by environmental and local authorities across rural areas of Neamt county. On the other hand, river dumping and open burning practices could mitigate the amounts of waste disposed of in local dumps, particularly in the mountain sector of Suceava, Neamt, and Bacau counties. Wild dumps are more consistent with the extra-Carpathian areas of the North-East Region, particularly in depression and plateau areas as shown in Figure 1. Secondly, there are two waste generation sources at the commune level that could contribute to open dumping practices: Inhabitants via uncollected household waste by waste operators and the economic agents (shops, pubs, institutions, local companies) that generate similar wastes, which feed the uncollected waste flow if there are no waste collection facilities across rural municipalities. Most of the waste generated in rural areas is provided by households $(80 \%)$ and economic agents $(20 \%)$, as suggested by master plans for waste management systems [37]. The basic waste indicators vary from one commune to another at the local scale as revealed in Neamt county [26]. This variation is common across rural communities because of non-homogenous social-economic, demographic, and geographic conditions.

Han et al. [1] found that in rural China, the characteristics of the household waste in towns or central villages were similar to those in cities but were different from those in common villages (the smallest type of community). In urban areas, the share of similar waste is expected to increase, particularly in large cities where business and public institutions are more developed.

If economic agents $(20 \%)$ are included as contributors to open dumping practices, the per-capita generation rate at the commune level increases from 0.31 to $0.4 \mathrm{~kg}^{\text {.inhab.day }}{ }^{-1}$ (regional average) and from 0.4 to $0.5 \mathrm{~kg}$.inhab.day ${ }^{-1}$ (national flat rate).

The resulting values decrease the share of dumps in the total uncollected waste at the county level, particularly for Iasi and Botosani counties. The regional average rate better explains the contribution of households (rural population) to waste dumping practices; the national flat rate (WGR $=0.4$ ) and the upper rate $(W G R=0.5)$ are consistent if economic agents are taken into consideration at the county level. Since there are poor coverage rates of WCS across the study area during 2003-2009, the contribution of economic agents to open dumping practices should not be ignored. Field observations reveal the 
fact that even rural localities covered by WCSs are still susceptible to illegal waste disposal practices due to the improper behavior of local residents, poor collection frequency, inadequate waste collection infrastructure, sanitation fees, etc.

Table 2. The ratio of uncollected household waste from rural dumps at the county level using different waste generation rates (WGRs).

\begin{tabular}{|c|c|c|c|c|c|c|c|c|}
\hline County & $\begin{array}{c}\text { Rural } \\
\text { Dumps (t) }\end{array}$ & $\begin{array}{l}\text { Kg Per } \\
\text { Capita }\end{array}$ & $\begin{array}{c}\text { Qhwu_t } \\
\left(2003 \_09\right) \\
\text { WGR = 0.31 } \\
\text { kg.inhab.day }\end{array}$ & $\begin{array}{l}\text { \% Qhwu of } \\
\text { DUMPs }\end{array}$ & $\begin{array}{c}\text { Qhwu_t } \\
(2003-09) \\
\text { WGR }=0.4\end{array}$ & $\begin{array}{c}\% \text { Qhwu of } \\
\text { Dumps }\end{array}$ & $\begin{array}{c}\text { Qhwu_t } \\
(2003-09) \\
\text { WGR }=0.5\end{array}$ & $\begin{array}{c}\% \text { Qhwu of } \\
\text { Dumps }\end{array}$ \\
\hline Bacau & $213,376.8$ & 536.51 & $276,405.97$ & 77.19 & $356,652.86$ & 59.82 & $445,816.08$ & 47.86 \\
\hline Botosani & 280,280 & 1043.02 & $210,087.83$ & 133.41 & $271,081.07$ & 103.39 & $338,851.34$ & 82.71 \\
\hline Iasi & $552,102.8$ & 1243.39 & $335,359.8$ & 164.62 & $432,722.32$ & 127.58 & $540,902.91$ & 102.07 \\
\hline Neamt & 35,318 & 99.84 & $248,553.09$ & 14.20 & $320,713.66$ & 11.01 & $400,892.08$ & 8.8 \\
\hline Suceava & 190,176 & 464.08 & $262,276.52$ & 72.50 & $338,421.32$ & 56.19 & $423,026.65$ & 44.95 \\
\hline Vaslui & 132,466 & 487.29 & $218,048.05$ & 60.75 & $281,352.32$ & 47.08 & $351,690.40$ & 37.66 \\
\hline North-East & $1,403,719.6$ & 654.16 & $1,550,731.28$ & 90.51 & $2,000,943.59$ & 70.15 & $2,501,179.48$ & 56.12 \\
\hline
\end{tabular}

\subsection{Assessment of Rural Waste Dumping Underestimation Level According to Scenario Analysis}

The data on dumpsite volumes at the EU region level does not cover the huge amounts of uncollected household waste during one year if noWCS are provided, as shown by the maps in Figure 4 . In this scenario, there are 217,903.591 tons of uncollected household waste $\left(\right.$ WGR $=0.31 \mathrm{~kg}$.inhab.day $\left.{ }^{-1}\right)$, which represents $15.5 \%$ of the total amounts reported to be disposed of in total dumps. The ratio of uncollected household waste in one year is more than $100 \%$ of rural dumpsites capacities reported by 130 communes (most of them located in Neamt county), between $75 \%$ and $100 \%$ in another 30 communes, and only in 37 communes the ratio is less than $5 \%$.

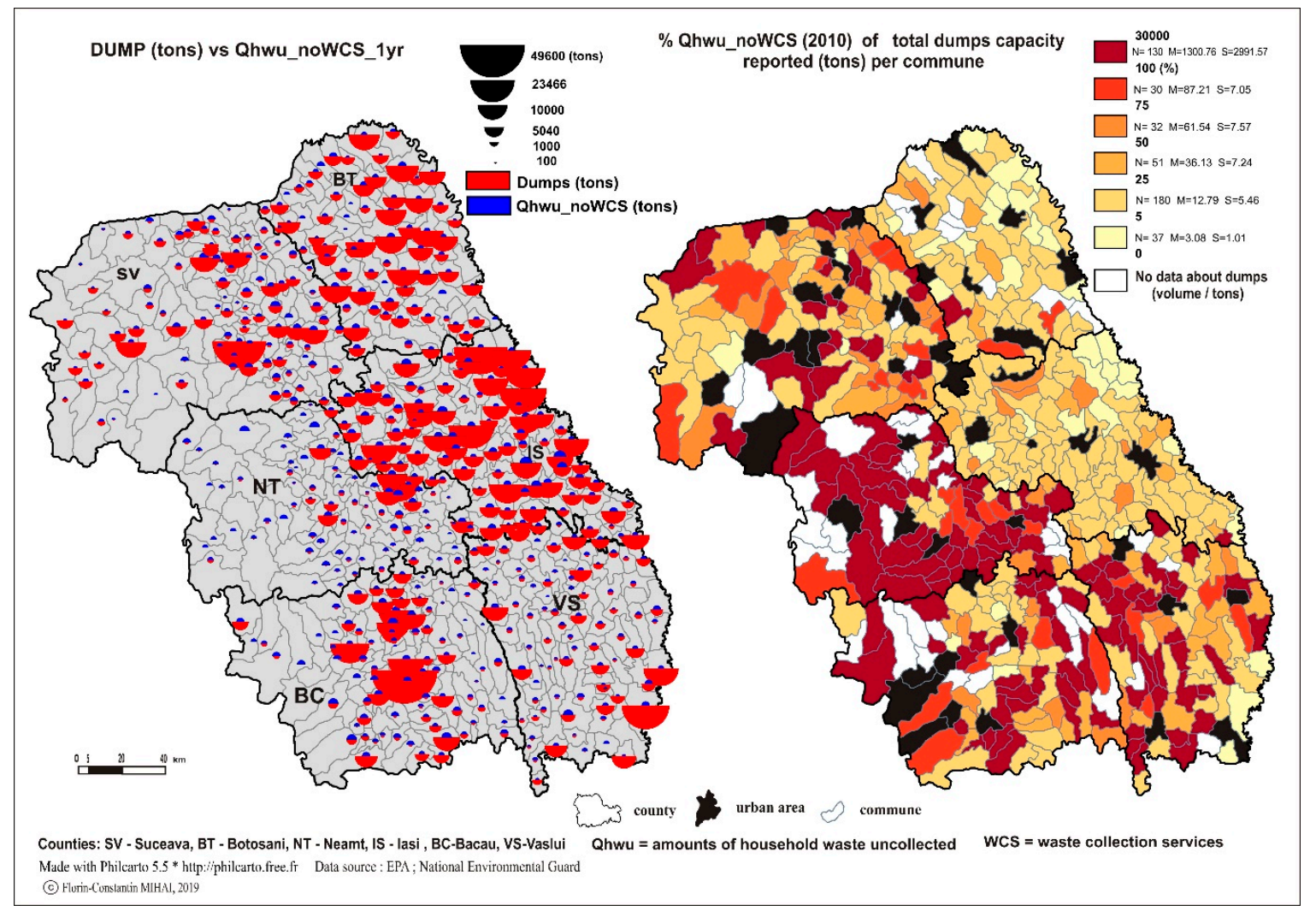

Figure 4. Household waste uncollected using noWCS scenario related to rural dumps. NoWCS = no access to waste collection services. 
Open dumping practices seem to be seriously underestimated in the case of 190 rural municipalities with incomplete data about rural dumpsites parameters across their administrative areas (Suceava, Neamt, Bacau, and Vaslui counties).

Waste diversion from wild dumps via river dumping and open burning of household waste could not cover all amounts of uncollected household waste. Home composting is also a diversion route in the case of biowaste fraction from wild dumps even if it is performed at the household level in open piles.

Food waste has a lower degree in rural areas of Czech Republic based on traditional recovery options, such as self-provision, cooking at home, and animal feeding [38].

A similar situation is valid across rural communities of the North-East Region, particularly in villages that are more distant to urban areas. Improper law enforcement and monitoring of illegal waste disposal practices leads to a poor assessment of waste dumping dimensions across rural communities. The same issue is highlighted in rural Poland, where the number of uncontrolled dumping sites revealed in the official statistics is underestimated and research on illegal waste disposal cannot be based on them [39].

Despite the fact that the regional database of wild dumps is the most comprehensive so far, this paper demonstrates that there are significant amounts of waste uncollected and uncovered by the dumpsites capacities reported by the local authorities, particularly in Neamt, Bacau, Suceava, and Vaslui counties.

Figure 5 shows that 226 communes (yellow polygons_right map) across the North-East Region have full coverage of WCS in 2010 with a better extension in Botosani, Iasi, and Suceava counties.

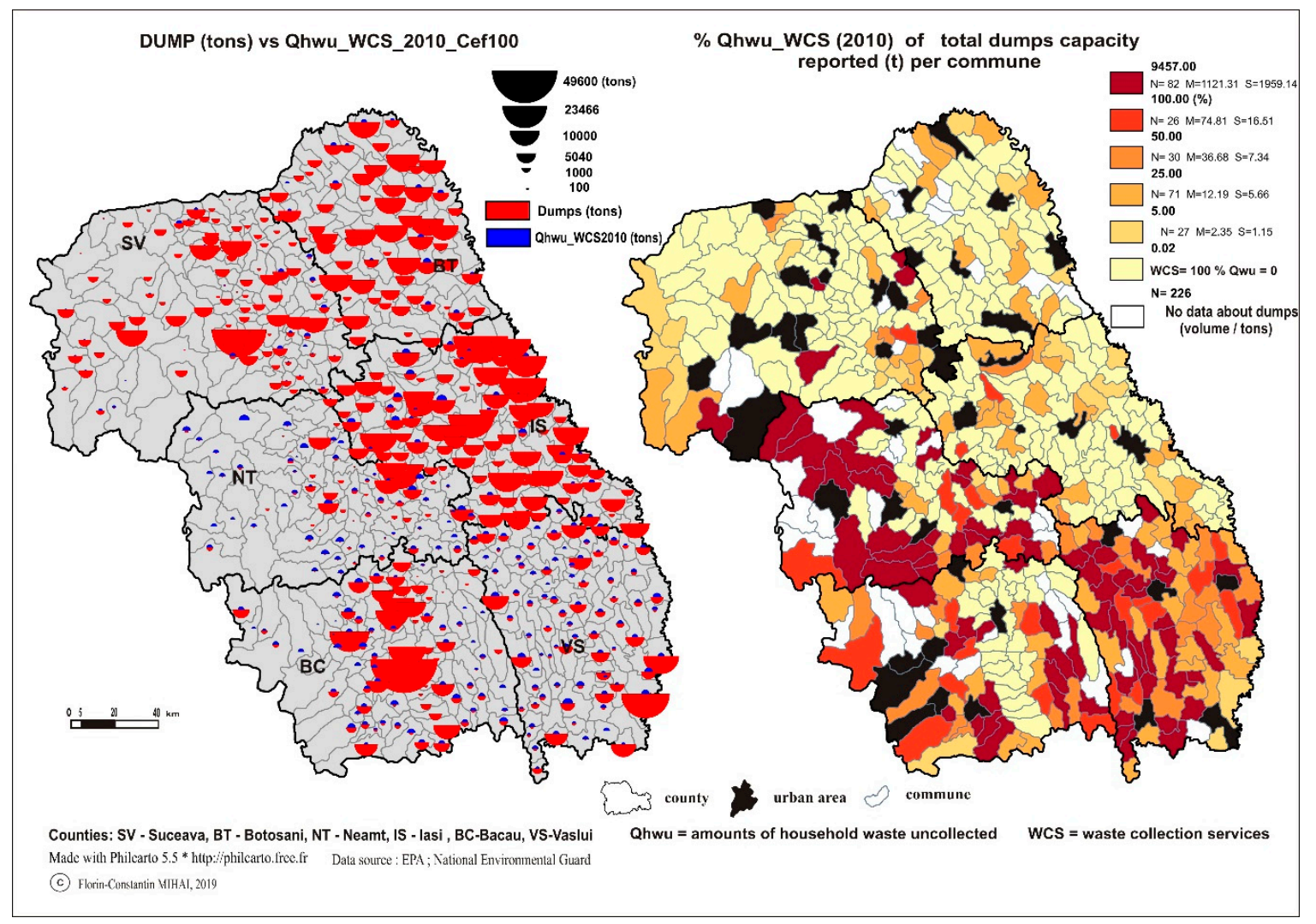

Figure 5. Household waste uncollected based on waste collection coverage rates in 2010 related to rural dumps $($ Cef $=100 \%)$. 
In such cases, the amounts of uncollected household waste are null since there are no inhabitants without access to such services, suggesting a full collection efficiency $(100 \%)$ as opposed to the noWCS scenario.

However, field observations show that even such communes are still facing illegal dumping practices, pointing out serious gaps in current rural waste management facilities. The illegal dumping of waste occurs even in high-income countries, such as England, where improvements in waste management, distribution facilities, and legal factors (law enforcement and prosecution actions of local councils), are required to combat this environmental threat [40].

The same actions need to be addressed in Romania both in urban and rural areas. Furthermore, if only the population unserved by WCS is taken into consideration at the commune level, there are several rural communities (82) that reported fewer amounts of waste disposed in dumps than those generated and uncollected in 2010 as shown in Figure 4. Most of the rural municipalities from Neamt, Bacau, and Vaslui counties are in this situation, only four communes in Suceava county, and none in Iasi and Botosani counties. In the case of Vaslui county, all communes have large amounts of uncollected household waste due to the lack of WCSs in rural areas in 2010. Thus, there are over 30 communes where the ratio of uncollected household waste in 2010 surpasses the total amounts disposed in the dumps from previous years. In this regard, the collection efficiency is a key factor to be considered for further estimations. Figure 6 shows a more realistic perspective than Figure 5 where the amounts of household waste generated and uncollected per commune are larger due to an inefficient waste collection system.

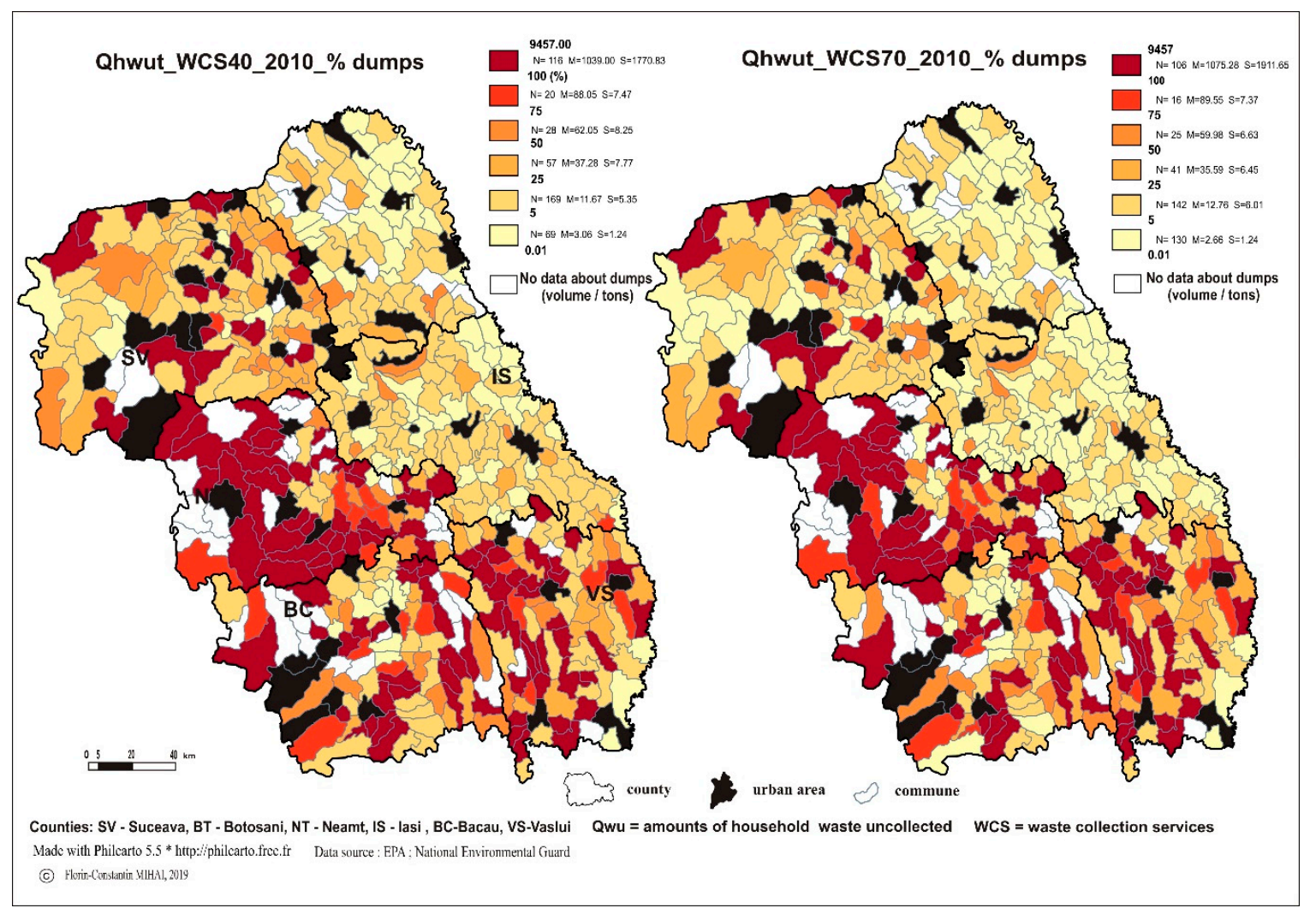

Figure 6. Household waste uncollected in 2010 based on low and upper collection efficiency scenarios related to rural dumps.

This fact is confirmed by previous studies [26,27] and by field observations. The main spatial patterns are still valid across these scenarios where the magnitude of waste dumping practices is seriously underestimated across Neamt, Vaslui, Bacau, and Suceava counties. 
There are 116 (WCS40) and 106 (WCS70) rural municipalities that generate in one year more uncollected household waste than that reported as disposed of in local dumps; 20 (WCS40) and 16 (WCS70) communes where the dump capacity should be filled over $75 \%$ as shown in Figure 5. On the opposite side, a higher collection efficiency leads to a larger number of communes (130), which contribute less than $5 \%$ of total local dumps compared to $69 \%$ in the case of poorer efficiency (40\%-low range).

This study demonstrates that even with a reasonable collection efficiency (WCS70), such as un upper range of middle-income countries like Romania in rural areas, the amounts of uncollected household waste could fill over $50 \%$ of the local dumps in only one year across 147 communes. These data resulted from such scenarios that argue that most of the rural waste dumping practices are out of official records without any knowledge about their repercussions to the natural environment or to public health issues. Furthermore, collection systems and treatment are still lacking in rural Romania and regulations are not still in action [41]. Capital investment in rural waste management services should be increased in low-income regions to relieve the burden of local municipalities as suggested by Cao et al. [42].

\subsection{Assessment of Uncollected Household Waste after the Closure of Rural Dumpsites (2010-2016)}

After the closure of rural dumpsites in 2009-2010, the expansion of waste collection coverage towards rural areas started to emerge, thus the amounts of household waste generated and uncollected by rural inhabitants without access to formal waste management sector have decreased since 2010 in the North-East Region from 109,141.79 tons to 48,998 tons in 2016 as shown in Figure 7. The total amount (540,849 tons) of uncollected household waste during 2010-2016 is one of the primary sources for environmental pollution by uncontrolled waste disposal activities (e.g., wild dumps, freshwater pollution, open burning practices, etc.).

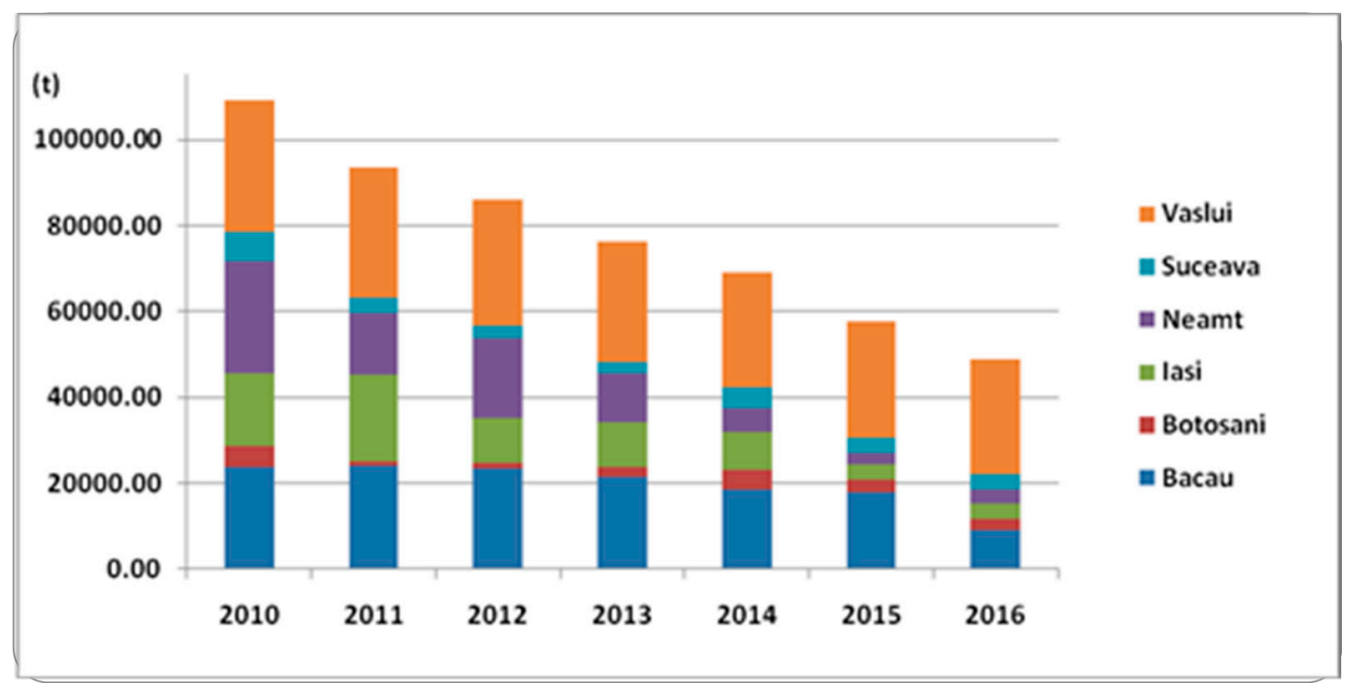

Figure 7. Household waste generated by rural population without access to WCSs during 2010-2016 in the North-East Region (data source: EPA environmental reports-author compilation).

Better waste collection coverage rates of rural areas across Iasi, Botosani, and Suceava counties led to lower amounts of uncollected household waste during this period. Neamt and Bacau counties made some progress in the latter years, but the situation in rural areas of Vaslui is still the worse of all the region. The rural waste collection coverage was under 10\% in 2016 in this county, therefore, the natural environment around rural settlements was significantly exposed to illegal dumping or open burning practices. In fact, 199,127.8 t of household waste was generated and uncollected in this county during $2010-2015$ as a ratio of $36.81 \%$ of the North-East Region. Bacau county contributed $138,238.5 \mathrm{t}$ of uncollected household waste and Botosani had the least amount, being under 20,000 $\mathrm{t}$. 
Full coverage of the rural population to waste collection schemes is expected in the following years due to the implementation of regional integrated municipal waste systems in each county of the region. Such systems stipulate the construction of one to two regional sanitary landfills (serving both urban and rural areas), transfer stations, and sorting and composting plants [24]. However, the delays associated with the construction of these new regional sanitary landfills, bureaucracy, tender process, and court decision have prolonged the waste management infrastructure crisis in Neamt, Bacau, Vaslui, and Suceava counties. The low and upper collection efficiency scenarios were further applied at the county level to determine the extra amount of household waste generated and uncollected in rural areas as an additional source to illegal dumping practices. Therefore, Table 3 points out that gaps in the waste collection schemes during 2010-2016, irrespective of low or upper collection efficiency rates, indicate that the total amounts of household waste cumulated surpass one million tons during 2010-2016. The cumulation of household waste generated by the rural population without access to WCS with the low range of collection efficiency of those covered by waste operators reveals huge amounts of household waste in each county, ranging from 144,274 $\mathrm{t}$ in Botosani County to 325,527 t in Vaslui County. These wastes are susceptible to uncontrolled disposal in the natural environment. The upper range reveals the key role played by better collection efficiency in rural areas, saving $511,410.85 \mathrm{t}$ of uncollected household waste at the North-East region level compared to the lower range (WCS40). In both cases, Bacau and Vaslui counties cumulated over 200,000 $t$ of uncollected household waste.

Table 3. Rural uncollected household waste flow based on collection efficiency scenarios during 2010-2016.

\begin{tabular}{ccccc}
\hline $\begin{array}{c}\text { County } \\
(\mathbf{2 0 1 0 - 2 0 1 6 )}\end{array}$ & Hwu_noWCS (t) & $\begin{array}{c}\text { Hwu_no WCS + } \\
\text { WCS40 (t) }\end{array}$ & $\begin{array}{c}\text { Hwu_noWCS + } \\
\text { WCS70 (t) }\end{array}$ & $\begin{array}{c}\text { Hwu_noWCS + } \\
\text { WCS60 (t)_NT }\end{array}$ \\
\hline Bacau & $138,238.56$ & $326,908.88$ & $232,573.72$ & $264,018.77$ \\
Botosani & $19,293.31$ & $144,274.46$ & $81,783.89$ & $102,614.08$ \\
Iasi & $74,315.99$ & $291,862.03$ & $183,089.01$ & $219,346.68$ \\
Neamt & $81,385.53$ & $249,097.05$ & $165,241.29$ & $193,193.21$ \\
Suceava & $\mathbf{2 8 , 4 8 7 . 9 6}$ & $\mathbf{2 2 6 , 0 0 0 . 8 1}$ & $127,244.39$ & $160,163.20$ \\
$\quad$ Vaslui & $199,127.82$ & $325,527.66$ & $262,327.74$ & $283,394.38$ \\
North East Region & $\mathbf{5 4 0 , 8 4 9 . 1 8}$ & $\mathbf{1 , 5 6 3 , 6 7 0 . 8 9}$ & $\mathbf{1 , 0 5 2 , 2 6 0 . 0 4}$ & $\mathbf{1 , 2 2 2 , 7 3 0 . 3 2}$ \\
$\quad$ (total) & & & & \\
\hline
\end{tabular}

Hwu_noWCS = household waste generated and uncollected of the population without access to WCS.

The collection efficiency based on the collection rate in Neamt county was applied to test the uncollected household waste flow as a middle range of the North-East Region. In this scenario, Bacau, Iasi (as the largest rural population at North-East Region level), and Vaslui counties generate the largest amounts of uncollected household waste. In the latter case, the unserved population is the biggest contributor in every situation to be taken into consideration.

Testing different parameters of collection efficiency scenarios reveals, on the one hand, that rural communities can generate large amounts of uncollected household waste, which can pollute the natural environment and on the other hand, the improvement of household waste capture by formal waste management systems is a crucial factor besides the full coverage of the rural population to waste collection schemes.

\subsection{Rural Waste Dumping Practices in Neamt County: A Comparative Analysis 2012-2015}

The expansion of WCS towards rural areas has emerged since the closure of rural dumpsites in 2009 , but illegal waste dumping practices still occur nowadays. In 2012, there were seven communes without access to formal WCS and several rural municipalities with partial coverage of such services. Figure 8 shows the uncollected household waste by inhabitants without access to sanitation services in 2012 (red fraction of the pie chart) compared to 2015, where all communes are connected to waste collection schemes. Thus, the population unserved by WCS generated 6434.9 tons of $17,236.7$ total 
tons of uncollected household waste in rural areas in 2012. In the latter case, the illegal dumping practices are associated with a poorer collection efficiency supported by field observations and previous studies, and on the other hand, by low collection rates during 2010-2015 as shown in Table 1. In 2015, rural communities generated 15,892.4 tons of uncollected household waste based on the WCS60 scenario. The amounts of the uncollected household waste range between 134 and 1153 tons at the commune level, taking into account both years.

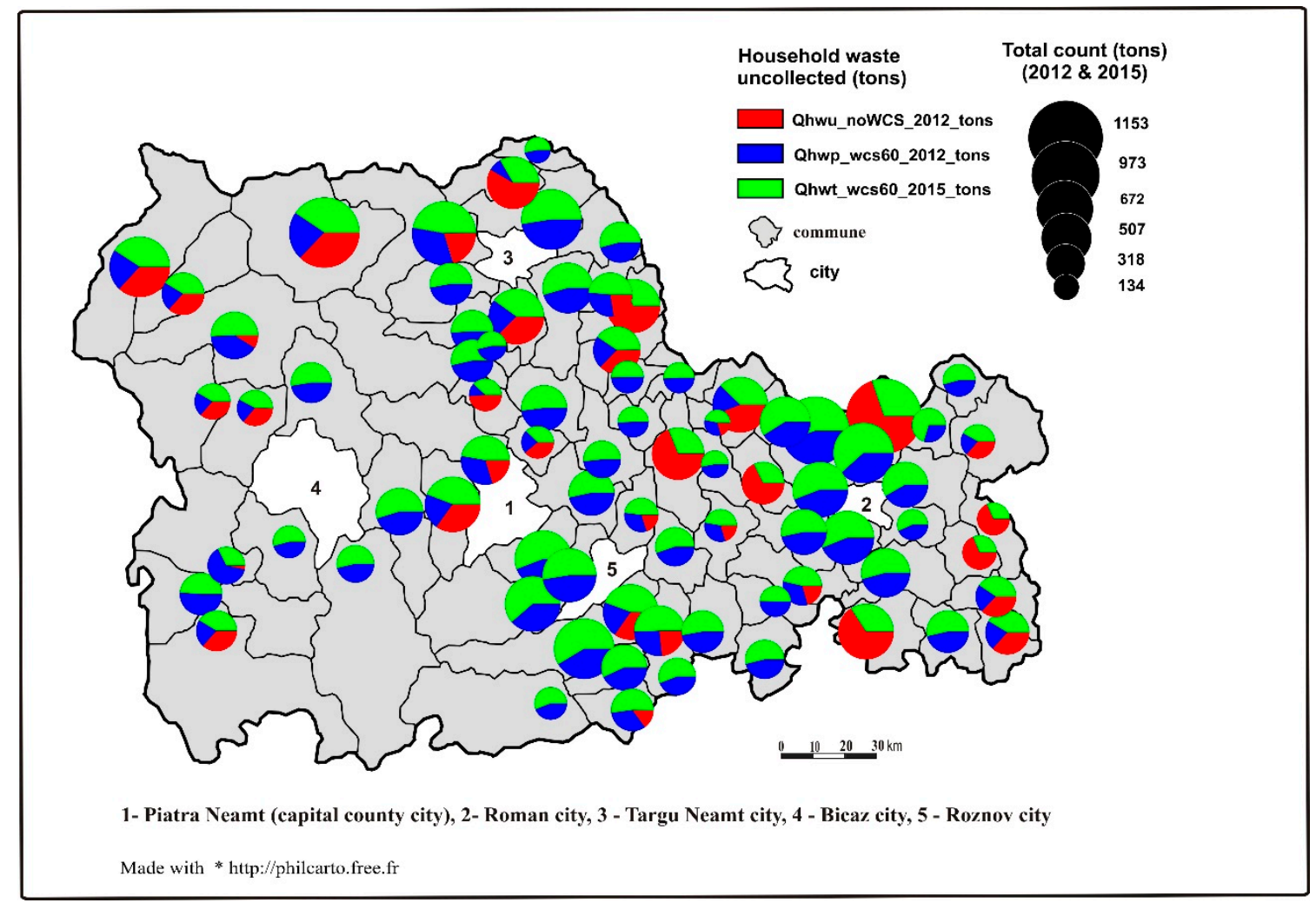

Figure 8. Uncollected household waste in rural areas of Neamt County in 2012 and 2015.

More than 30 communes did not have full coverage of WCS in 2012 (blue fraction of the pie chart), which, combined with a collection efficiency of $60 \%$, led to larger amounts of households' uncollected waste being susceptible to uncontrolled disposal in comparison to 2015.

The most vulnerable rural areas to illegal dumping practices are situated in the eastern and south-eastern parts of the county outside of those seven communes with no such services in 2012 (without a blue section of the pie chart). Furthermore, well-populated communes located in the south of Piatra Neamt city (county capital) generate large amounts of uncollected household waste prone to illegal waste dumping practices. Most of the waste operators signed contracts with local authorities rather than directly with inhabitants, thus gaps are expected in waste collection schemes. This fact could explain the lower collection rates during 2010-2015 despite the total rural waste collection coverage being $94 \%$ in 2015 at the county level. The higher collection, transportation, and landfill costs caused by the closure of non-compliant landfills from Targu Neamt, Bicaz, and Roman cities are transferred into rural sanitation fees paid by the rural population served. In this context, some people refuse to pay for waste management services and wastes generated are improperly disposed of via wild dumps or open burning practices [29].

The above situations reveal the routes for illegal waste dumping practices despite the presence of waste operators in rural areas or even full coverage of the population to such services. 


\section{Development of the Rural Circular Economy Framework}

A circular economy is becoming a key strategic framework for EU sustainability being dedicated to several actions to achieve decoupling from the current linear economy model [43].

The circular economy involves a multi-sectoral approach and complex interactions between various stakeholders [44], where industry, agriculture, commerce, and tourism can make the transition to such a model at regional levels [45] besides a reliable solid waste management system. New recycling targets are set for the overall municipal waste fraction (65\% as the recycling rate by 2035$)$ and $70 \%$ for recycling $70 \%$ of packaging waste by 2030 and special targets for some special packaging materials for plastics $(55 \%)$, paper/cardboard $(85 \%)$, glass $(75 \%)$, and ferrous metals $(80 \%)$ to be fulfilled by all EU) [46]. Romania must upgrade as soon as possible the current waste management systems to cover both urban and rural areas to separate collection schemes, sorting stations, composting plants, transfer stations, and regional sanitary landfills in order to successfully achieve these new EU targets related to circular economy policies.

\subsection{New Regional Integrated Waste Management Systems}

Rural areas must be integrated into regional waste management systems where the main facilities are frequently located around the cities. Different rural areas within a county will be connected to transfer stations of urban areas in the proximity. On such sites, recyclables will be sorted and processed to be further sold to recycling companies. The residual waste (mixed fraction) with poor recycling potential will be transported to the regional sanitary landfill site. In the first stage, all communes within a county must be connected to waste collection schemes provided by public services or private waste operators. Secondly, the source-separated collection facilities via collection points (e.g., dry recyclables) or from door-to-door schemes are basic steps to stimulate recycling operations. Waste collection frequency should be at least every week for residual waste and no more than 2 weeks for dry recyclables (plastics, metals, glass, paper/cardboard).

Collection points must be carefully located across rural communities taking into account the distances from households and the collection points. In fact, door-to-door collection schemes seem to be more efficient in mountainous areas or rural settlements displayed along the watercourse and their tributaries [26]. Collection points are more feasible for compact and populated rural areas, particularly in the proximity of urban areas. Special waste streams, such as e-waste, used tires, bulky waste, construction, and demolition waste, batteries and accumulators, end-of-life vehicles, and hazardous items, must be collected through special collection campaigns or brought to urban recycling centers by individuals. In this regard, environmental and local municipalities should initiate environmental awareness events about the critical role played by special waste collection events for such types of waste. Local economic agents and public institutions must manage their own packaging waste stream or delegate a specialized waste operator to collect and further process this waste stream as part of the extended producer responsibility scheme). Some rural economic agents could serve as a local collection point for such special waste streams (e.g., batteries and accumulators, e-waste, used oil, etc.) in partnership with recycling companies. A source-separated waste collection based on four waste fractions has been compulsory since 1 July 2019 according to the updated waste management law [47], at least in the case of plastics, metals, paper and cardboard, and glass beside the residual waste of the municipal waste stream. Furthermore, these waste fractions must be reached by December 31 2020, a level for reuse and recycling at least $50 \%$ of the total mass generated. This target is hard to achieve in rural areas where separate collection schemes are just being implemented. The landfill fee will increase to 80 lei per ton (1 leu $=4.7 \mathrm{EUR}$ ) in 2020 as a measure to discourage the landfill of waste and to fund recycling and recovering initiatives through the Environmental Fund Administration. The regional waste management plans must be updated at each county level of the North-East Region according to the new National Waste Management Plan [24]. 


\subsection{Home Composting and Animal Feed}

These are traditional routes for biowaste fraction of municipal waste stream across rural communities. In rural Romania, subsistence agriculture still prevails among households, thus biowaste is regarded as a cheap resource for obtaining natural fertilizers for farming activities. The older habits use animal manure combined with garden waste and food waste (vegetables) to make compost on open piles. However, this is a rude technique performed on direct soil, which can pollute the local environment through emissions to air, soil, and groundwater bodies. New composting bins and special platforms for the storage of organic waste should be implemented via regional waste management systems following the steps provided in guidelines.

Composting plays a key role in the rural circular paradigm due to the high share of organic waste in the MSW stream. Also, the Landfill Directive 1999/31/EC requires the reduction of biodegradable waste to be disposed of in urban landfills; therefore, home composting activities or centralized composting facilities must treat most biowaste flows fed by rural communities. Besides composting activities, animal feed (bones, meat, other food items, crop residues as fodder) is another key alternative for rural communities. Home composting and animal feed are key alternatives for less developed regions and sparsely populated rural settlements in managing organic wastes [48]. Rural-urban linkages could stimulate biowaste prevention and organic farming. As an example, a food waste diversion program was initiated by retailers and restaurants (hotels), which is sorted and sent to compost in a rural bio farm (Ciocanesti, Dimbovita County). This initiative collected 621 tons of organic waste, producing 595 tons of compost, Another 26 tons of vegetables and fruits have been saved and donated and this project delivered 5200 meals to elderly people, those with disabilities, or homeless people [49].

\subsection{Community Waste Management and Creative Reuse of Waste Items}

Distant rural localities from urban centers face more challenges in managing their MSW stream due to the reluctance of waste operators to cover such areas and supplementary costs related to the transportation of waste collected towards recycling and disposal facilities. In this context, rural communities must implement traditional (e.g., home composting, animal feed, recovery and reuse of waste items at the household level) and innovative routes (e.g., upcycling or creative reuse, refurbishment of computers and other IT equipment) to combat illegal dumping and open burning practices and to avoid landfill of the MSW stream as much as possible. Figure 9 shows the traditional routes and formal waste management routes to make the transition from linear to circular economy model and to combat major environmental threats associated with improper waste management activities. There is a guide Making Waste Work that can help rural communities of lowand middle-income countries (including rural Romania) manage their waste using simple and low-cost techniques and foster local recycling enterprises and a local economy [50].

Urbanization process, construction sector, and the expansion of infrastructure (roads, public utilities, etc.) are expected to increase in the following years in Romania. The rural areas will be vulnerable to a huge amount of construction and demolition wastes (C\&DW) if there is not sufficient treatment capacities. Mobile crushing plants could be an optimal solution for rural communities to deal with C\&DW flows. This waste stream has a high potential for reuse, recovery, and recycling activities under circular economy prospects as new building materials for both urban and rural areas [51].

Rural creative reuse has started to be observed in some rural municipalities: polyethylene terephthalate (PET)bottles are used to decorate the gates of pubs; plastics bottles caps are used to build household gates according to the local traditional customs (e.g., Blaga village, Iasi County). Various waste streams (plastics, paper/cardboard, wood, textile, e-waste, etc.) are reused to create new kinds of items useful in households. This activity could be an additional source of income but will imply challenges related to the provision, transport, storage, and delivery of products. 


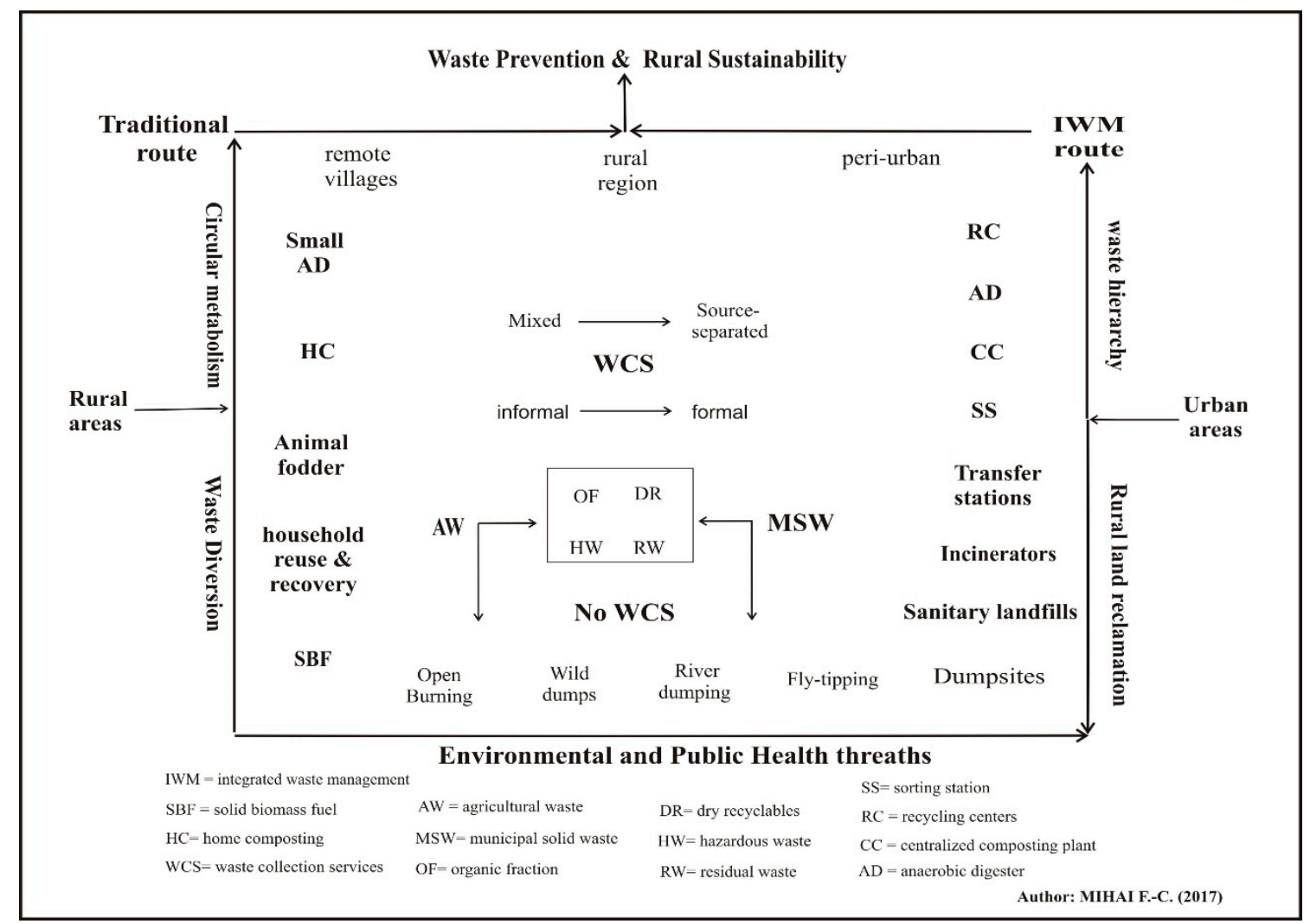

Figure 9. Pathways towards waste prevention and rural sustainability. Source: Mihai and Taherzadeh 2017 (CC-BY license) [2].

A wide range of activities related to upcycling can be performed with the support provided by specialized organizations, such as http://reciclarecreativa.ro/. At the EU level, there is a policy handbook to stimulate creative partnerships through upcycling activities that was created in 2014 [52]. However, the impact of upcycling is limited so far in rural areas, but such practices could spread the environmental awareness and zero waste concept towards a larger audience supported also by schools, mass-media, social media, local stakeholders, non-governmental organizations (NGOs), etc. Internet coverage across rural areas has emerged in the last years, thus inhabitants could learn about upcycling activities and how to embrace waste prevention initiatives under the zero waste paradigm. The zero waste concept emerges at the European level (https://zerowasteeurope.eu/) with the national organization from the EU (including Romania) and non-EU countries. Zero waste, defined as "the conservation of all resources by means of responsible production, consumption, reuse and recovery of products, packaging, and materials without burning, and with no discharges to land, water, or air that threaten the environment or human health" https://zerowasteeurope.eu/what-is-zero-waste/, is supported by Zero Waste International Alliance. However, this zero-waste concept seems to emerge in cities but such a concept must be adapted to diverse features of rural regions. In this context, the role of NGOs could be significant in consolidating practices of 3, 6, or 9Rs (reduce, reuse, repair, recovery, refurbish, repurpose, remanufacture, recycle, refuse) in rural communities.

An example of e-waste recycling activities combined with social inclusion is the WISE WEEE project, which aims to keep the maximum value of products in the country using local labor of marginalized groups (women and men with a disability, chronic diseases, family, justice, or poverty issues, addictions, etc.) from Bucharest city [53]. These types of social enterprises could be reliable alternatives for rural communities of the North-East Region, which are more vulnerable to social exclusion associated with lack of investments, job opportunities, and poverty issues. Education and environmental awareness campaigns among pupils and students seem to be key factors in the long 
term concerning the adoption of a zero-waste lifestyle to prevent waste generation as much as possible at the household level and to consolidate the circular economy in urban and rural areas [54,55].

\section{Conclusions}

The lack of WCSs prior to the closure of rural dumpsites (2003-2009) contributed to large amounts of uncollected household waste in each county of the study area, ranging from 335,359.8 tons in Iasi county to 210,087.83 tons in Botosani county. The closure process of rural wild dumps (2009-2010) provided the most comprehensive database at North-East Region level concerning the volumes of such sites but the paper points out serious gaps at the local scale (LAU2) within a county or between western and eastern counties of this peripheral EU region. The ratio of open dumping practices of total uncollected household waste is higher in eastern counties (70-80\%) than mountainous areas of Suceava, Neamt, and Bacau counties, where river dumping practices (including plastic pollution) could be a widespread alternative option as pointed out in a previous study $[27,30]$.

Several rural communities (181 communes) disposed less than $200 \mathrm{~kg} /$ inhab.year $^{-1}$ in wild dumps (as reported values), which is almost equivalent to the amount generated by one person if rural waste generation is $0.31,0.4$, or even $0.5 \mathrm{~kg}$.inhab.day ${ }^{-1}$. The environmental pollution dimension associated with rural waste dumping practices is seriously underestimated taking into account only the gross empirical data resulting from the closure procedure of reported wild dumps. The maps combined with scenario analysis revealed that 130 rural municipalities generate, in one year, more wastes than that reported as dumped on the surroundings from previous years (noWCS scenario). Furthermore, 82 communes generated more household waste than that disposed of in rural dumps and the other 26 rural communities generated more than $50 \%$ of the total dump capacity per commune in the best-case scenario where the collection efficiency was 100\%. Despite the fact that no rural WCS were provided in Vaslui county during 2009-2010, 30 communes generated in 2010 more household wastes than those disposed of in dumps in previous years. This poor situation prevailed during 2010-2016, where 199,127.8 tons of household waste were generated and uncollected as a ratio of $36.81 \%$ of the North-East Region. The extension of full WCSs towards rural communities emerged during 2010-2016 as a basic step to avoid the illegal dumping of solid waste, but it is not a sufficient factor. However, the amount of household waste generated by the rural population without access to WCSs decreased to 540,849 tons (2010-2016) compared to 1,550,731 tons prior to the closure of rural dumpsites (2003-2009). Collection efficiency is not expected to be $100 \%$ across rural municipalities and more uncollected household waste is leaking into the natural environment as suggested by the low and upper ranges of collection efficiency scenarios (WCS40 and WCS70) specific to the case of a middle-income country like Romania.

The total amount of uncollected household waste derived from the population without access to WCSs combined with that due to gaps in the waste collection schemes could reach over 1 MT of uncollected household waste at the North-East Region level, irrespective of the collection efficiency scenario used. These amounts of household waste are primary sources of waste-related pollution in rural areas besides other possible waste streams (e.g., construction and demolition waste, agricultural wastes). The rural waste dumping practices may vary in terms of the type and magnitude at different geographical scales from one county to another or between villages of a commune. This was confirmed in the case of Neamt county, where the rural collection rate was below the regional waste generation rate during 2012-2015 (average $0.18 \mathrm{~kg}$ vs. $0.31 \mathrm{~kg}^{2}$.inhab.day ${ }^{-1}$ ) and the calculated collection efficiency was $60 \%$. The poor collection rates performed by waste operators highlight the current gaps in the rural waste collection schemes, which feeds illegal waste dumping practices. The paper estimated 33,129.1 tons of uncollected household waste in 2012 and 2015 prone to waste dumping practices across rural communities of Neamt county.

The paper points out that the traditional routes (home composting, animal feed, household recovery of waste items) must be further improved and supported by the rural community besides 
formal regional integrated waste management systems coupled with innovative projects or activities that stimulate creative reuse, the zero waste concept, and social solidarity.

Further investigations are necessary to reveal the exposure of rural communities towards unsound waste dumping practices across the transition and developing countries and to examine cost-efficient options towards a rural circular economy.

Author Contributions: F.-C.M.—developed the conceptualization of the paper and the methodology, gathered the data, performed the analysis and figures, writing the first draft of the manuscript. A.G.-literature review and revision of the manuscript draft

Funding: The APC is supported by Department of Geography, Faculty of Geography and Geology. This research work was supported by a grant of the Alexandru Ioan Cuza University of Iasi, within the Research Grants program, Grant UAIC, code GI-UAIC-2017-06.

Conflicts of Interest: The author declares no conflict of interest. The funders had no role in the design of the study; in the collection, analyses, or interpretation of data; in the writing of the manuscript, or in the decision to publish the results.

\section{References}

1. Han, Z.; Liu, Y.; Zhong, M.; Shi, G.; Li, Q.; Zeng, D.; Zhang, Y.; Fei, Y.; Xie, Y. Influencing factors of domestic waste characteristics in rural areas of developing countries. Waste Manag. 2018, 72, 45-54. [CrossRef] [PubMed]

2. Mihai, F.-C.; Taherzadeh, M.J. Introductory Chapter: Rural Waste Management Issues at the Global Level. In Solid Waste Management in Rural Areas; Mihai, F.-C., Ed.; IntechOpen: Rijeka, Croatia, 2017. [CrossRef]

3. Hoornweg, D.; Bhada-Tata, P. What a Waste: A Global Review of Solid Waste Management, Urban Development Series Knowledge Papers; World Bank: Washington DC, USA, 2012; Available online: http://documents. worldbank.org/curated/en/2012/03/16537275/waste-global-review-solid-wastemanagement (accessed on 15 March 2012).

4. Triassi, M.; Alfano, R.; Illario, M.; Nardone, A.; Caporale, O.; Montuori, P. Environmental pollution from illegal waste disposal and health effects: A review on the "Triangle of Death". Int. J. Environ. Res. Public Health 2015, 12, 1216-1236. [CrossRef] [PubMed]

5. Borrell, R.J.; Rodríguez, F.R.; Monedero, A.L.L. Factor analysis and geographic information system for determining probability areas of presence of illegal landfills. Ecol. Ind. 2014, 37, 151-160. [CrossRef]

6. Sedova, B. On causes of illegal waste dumping in Slovakia. J. Environ. Plan Man. 2016, 59, 1227-1303. [CrossRef]

7. Stanisavljević, N.; Ubavin, D.; Batinić, B.; Fellner, J.; Vujić, G. Methane emissions from landfills in Serbia and potential mitigation strategies: A case study. Waste Manag. Res. 2012, 30, 1095-1103. [CrossRef] [PubMed]

8. Zeng, C.; Niu, D.; Zhao, Y. A comprehensive overview of rural solid waste management in China. Front. Environ. Sci. Eng. 2015, 9, 949-961. [CrossRef]

9. Taherzadeh, M.J.; Rajendran, K. Factors Affecting the Development of Waste Management. Experiences from Different Cultures. In Waste Management and Sustainable Consumption: Reflections on Consumer Waste; Ekström, K.M., Ed.; Routledge: Abingdon, UK, 2015; pp. 67-88.

10. Poldnurk, J. Optimisation of the economic, environmental and administrative efficiency of the municipal waste management model in rural areas. Resour. Conserv. Recycl. 2015, 97, 55-65. [CrossRef]

11. Stanic-Maruna, I.; Fellner, J. Solid waste management in Croatia in response to the European Landfill Directive. Waste Manag. Res. 2012, 30, 825-838. [CrossRef]

12. Panaretou, V.; Malamis, D.; Papadaskalopoulou, C.; Sotiropoulos, A.; Valta, K.; Margaritis, M.; Plevri, A.; Moustakas, K.; Loizidou, M. Implementation, and evaluation of an integrated management scheme for MSW in selected communities in Tinos Island, Greece. Waste Biomass Valor. 2016. [CrossRef]

13. De Morais Lima, P.; Paulo, P.L. Solid-waste management in the rural area of BRAZIL: A case study in Quilombola communities. J. Mater. Cycles Waste Manag. 2018, 20, 1583-1593. [CrossRef]

14. Wu, X.; Yue, B.; Huang, Q.; Wang, Q.; Li, Z.; Wang, Y.; Yu, J. Investigation of the physical and chemical characteristics of rural solid waste in China and its spatiotemporal distributions. Environ. Sci. Pollut. Res. 2018, 25, 17330-17342. [CrossRef] [PubMed] 
15. Cucchiella, F.; D'Adamo, I.; Gastaldi, M. Sustainable Italian Cities: The Added Value of Biomethane from Organic Waste. Appl. Sci. 2019, 9, 2221. [CrossRef]

16. Florkowski, W.J.; Us, A.; Klepacka, A.M. Food waste in rural households supports for local biogas production in Lubelskie Voivodeship. Resour. Conserv. Recycl. 2018, 136, 46-52. [CrossRef]

17. Ciura, D.; Łukasiewicz, M.; Malinowski, M. Analysis of morphological composition of wastes deposited on illegal dumping sites located in the area of Olsztyn district. Infrastruct. Ecol. Rural Areas 2017, 1301-1315. [CrossRef]

18. Macias, A.; Piniarski, W. Municipal Solid Waste Management Problems on a Local Scale: A Case Study from Rural Poland. Pol. J. Environ. Stud. 2016, 25, 1623-1632. [CrossRef]

19. Castillo-Giménez, J.; Montañés, A.; Picazo-Tadeo, A.J. Performance in the treatment of municipal waste: Are European Union member states so different? Sci. Total Environ. 2019, 687, 1305-1314. [CrossRef]

20. Hidalgo, D.; López, F.; Corona, F.; Martín-Marroquín, J.M. A novel initiative to counteract illegal dumping in rural areas of Valladolid Province. Environ. Sci. Pollut. Res. 2019. [CrossRef]

21. European Commission. Regions and Cities Illustrated (RCI). Available online: https://ec.europa.eu/eurostat/ cache/RCI/\#?vis=nuts2.economy\&lang=en (accessed on 12 October 2019).

22. ADR Nord-Est 2013 Regional Development Strategy of Nort-East 2014-2020. Available online: http: //www.adrnordest.ro/user/file/pdr/v3/strategie\%20RNE\%202014-2020\%20aprilie\%202013.pdf (accessed on 14 January 2018). (In Romanian).

23. Ciuta, S.; Apostol, T.; Rusu, V. Urban and Rural MSW Stream Characterization for Separate Collection Improvement. Sustainability 2015, 7, 916-931. [CrossRef]

24. National Waste Management Plan (Version 5, 2 November 2018). Available online: http://mmediu.ro/app/ webroot/uploads/files/PNGD_vers5.pdf (accessed on 14 January 2018). (In Romanian).

25. National Environment Protection Agency (NEPA). The State of the Environment Report in 2016; NEPA: Bucharest, Romania, 2017.

26. Mihai, F.C. Waste collection in rural communities: Challenges under EU regulations. A case study of Neamt County, Romania. J. Mater. Cycles Waste Manag. 2018, 20, 1337-1347. [CrossRef]

27. Mihai, F.-C. Rural plastic emissions into the largest mountain lake of the Eastern Carpathians. R. Soc. Open Sci. 2018, 5, 172396. [CrossRef]

28. Environment Protection Agency of Neamt County. The State of the Environment Report in 2017; Protection Agency of Neamt County: Neamt County, Romania, 2018.

29. Mihai, F.C.; Banica, A.; Grozavu, A. Backyard burning of household waste in rural areas. Environmental impact focusing on air pollution. In Proceedings of the 19th International Multidisciplinary Scientific GeoConference on Ecology, Economics, Education and Legislation SGEM, Albena, Bulgaria, 28 June-7 July 2019; Volume 19, pp. 55-62. [CrossRef]

30. Mihai, F.C.; Minea, I.; Grozavu, A. Assessment of waste dumping practices in mountain creeks. In Proceedings of the 18th International Multidisciplinary Scientific GeoConference on Ecology, Economics, Education and Legislation SGEM, Albena, Bulgaria, 2-9 July 2018; Volume 18, pp. 89-96. [CrossRef]

31. Malinowski, M.; Wolny-Koladka, K.; Jastrzebski, B. Characteristics of Illegal Dumping Sites-Case Study: Watercourses. Infrastruct. Ecol. Rural Areas 2015, 4, 1475-1484.

32. Quesada-Ruiz, L.; Rodriguez-Galiano, V.; Jordá-Borrell, R. Identifying the main physical and socioeconomic drivers of illegal landfills in the Canary Islands. Waste Manag. Res. 2018. [CrossRef] [PubMed]

33. Vaverková, M.D.; Winkler, J.; Adamcová, D.; Radziemska, M.; Uldrijan, D.; Zloch, J. Municipal solid waste landfill-Vegetation succession in an area transformed by human impact. Ecol. Eng. 2019, 129, 109-114. [CrossRef]

34. Skryhan, H.; Shilova, I.; Khandogina, O.; Abashyna, K.; Chernikova, O. Waste management in post-soviet countries: How far from the EU? Detritus 2018, 3, 193-203. [CrossRef]

35. Fedotkina, O.; Gorbashko, E.; Vatolkina, N. Circular Economy in Russia: Drivers and Barriers for Waste Management Development. Sustainability 2019, 11, 5837. [CrossRef]

36. Semernya, L.; Ramola, A.; Alfthan, B.; Giacovelli, C. Waste management outlook for mountain regions: Sources and solutions. Waste Manag. Res. 2017, 35, 935-939. [CrossRef] [PubMed]

37. MPCT-Master. Plan for Integrated Waste Management System in Constanta County; Louis Berger: Morristown, NJ, USA, 2016. 
38. Sosna, D.; Brunclíkov, L.; Galeta, P. Rescuing things: Food waste in the rural environment in the Czech Republic. J. Clean Prod. 2019, 214, 319-330. [CrossRef]

39. Jakiel, M.; Bernatek-Jakiel, A.; Gajda, A.; Filiks, M.; Pufelska, M. Spatial and temporal distribution of illegal dumping sites in the nature protected area: The Ojców National Park, Poland. J. Environ. Plan Man. 2018. [CrossRef]

40. Liu, Y.; Kong, F. Santibanez Gonzalez, EDR. Dumping, waste management, and ecological security: Evidence from England. J. Clean Prod. 2017, 167, 1425-1437. [CrossRef]

41. Ferronatoa, N.; Rada, E.C.; Portillo, M.A.G.; Cioca, L.I.; Ragazzi, M.; Torretta, V. Introduction of the circular economy within developing regions: A comparative analysis of advantages and opportunities for waste valorization. J. Environ. Manag. 2019, 230, 366-378. [CrossRef]

42. Cao, S.; Xu, D.; Liu, S. A Study of the Relationships between the Characteristics of the Village Population Structure and Rural Residential Solid Waste Collection Services: Evidence from China. Int. J. Environ. Res. Public Health 2018, 15, 2352. [CrossRef] [PubMed]

43. European Commission. Closing the loop-An EU Action Plan for the Circular Economy. 2015. Available online: https://eurlex.europa.eu/legalcontent/EN/TXT/?uri=CELEX:52015DC0614 (accessed on 27 October 2019).

44. Rosa, P.; Sassanelli, C.; Terzi, S. Towards Circular Business Models: A systematic literature review on classification frameworks and archetypes. J. Clean. Prod. 2019, 117696. [CrossRef]

45. Falcone, P.M. Green investment strategies and bank-firm relationship: A firm-level analysis. Econ. Bull. 2018, 38, 2225-2239.

46. European Parliament. Directive (EU) 2018/852 of the European Parliament and of the Council of 30 May 2018 amending Directive 94/62/EC on packaging and packaging waste. Official Journal of the European Union L150/141. Available online: https://eur-lex.europa.eu/legal-content/EN/TXT/?uri=uriserv: OJ.L_.2018.150.01.0141.01.ENG\&toc=OJ:L:2018:150:TOC (accessed on 10 October 2019).

47. Emergency Ordinance No. 74/2018 for amending and supplementing Law No. 211/2011 regarding the waste regime, of Law No. 249/2015 regarding the management of packaging and packaging waste and the Government Emergency Ordinance No. 196/2005 regarding the Environmental Fund.

48. Mihai, F.C.; Ingrao, C. Assessment of biowaste losses through unsound waste management practices in rural areas and the role of home composting. J. Clean. Prod. 2018, 172, 1631-1638. [CrossRef]

49. AFF. Activity Report. 2018. Available online: https://static1.squarespace.com/static/ 5a463ececd39c39db5dbfc31/t/5d0b545759148f000129b0fb/1561023600224/AFF+2018+Raport+Activitate+ _Ro+_+Pagina+cu+Pagina.pdf (accessed on 27 October 2019).

50. WasteAid UK Making Waste Work: A Toolkitt Retrieved 29 October 2019. Available online: https: //wasteaid.org/toolkit/making-waste-work/ (accessed on 29 October 2019).

51. Mihai, F.-C. Construction and demolition waste in Romania: The route from illegal dumping to building materials. Sustainability 2019, 11, 3179. [CrossRef]

52. European Agenda for Culture. Policy Handbook on the Promotion of Creative Partnerships. 2014. Available online: https:/ec.europa.eu/assets/eac/culture/library/reports/creative-partnerships_en.pdf (accessed on 10 October 2019).

53. Ateliere Fara Frontiere. Wise WISE. Available online: https://issuu.com/atelierefarafrontiere/docs/wise_ weee_booklet (accessed on 10 October 2019).

54. Saseanu, A.S.; Gogonea, R.-M.; Ghita, S.I.; Zaharia, R.Ş. The Impact of Education and Residential Environment on Long-Term Waste Management Behavior in the Context of Sustainability. Sustainability 2019, 11, 3775. [CrossRef]

55. Laurenti, R.; Martin, M.; Stenmarck, Å. Developing Adequate Communication of Waste Footprints of Products for a Circular Economy-A Stakeholder Consultation. Resources 2018, 7, 78. [CrossRef]

(C) 2019 by the authors. Licensee MDPI, Basel, Switzerland. This article is an open access article distributed under the terms and conditions of the Creative Commons Attribution (CC BY) license (http://creativecommons.org/licenses/by/4.0/). 